\title{
Spectacle, Speculatıve, Spectıle: Situations in Sarah Kane, Sevim Burak, etc
}

\section{Zafer Aracagök \& P Burcu Yalim}

To cite this article: Zafer Aracagök \& P Burcu Yalim (2010) Spectacle, Speculatıve, Spectıle: Situations in Sarah Kane, Sevim Burak, etc, Third Text, 24:4, 437-444, DOI: 10.1080/09528822.2010.491374

To link to this article: https://doi.org/10.1080/09528822.2010.491374

曲 Published online: 05 Jul 2010.

Submit your article to this journal $\pi$

Џlll Article views: 216 


\section{Spectacle, Speculatıve, Spectıle Situations in Sarah Kane, Sevim Burak, etc}

\section{Zafer Aracagök and P Burcu Yalim}

1. Sarah Kane, ' 4.48 Psychosis', in Complete Plays, Methuen Drama, London, 2001, p 205

2. Gilles Deleuze and Félix Guattari, Anti-Oedipus: Capitalism and Schizophrenia, trans Robert Hurley, Mark Seem and Helen R Lane, Continuum, London, 2008, pp 84-5

3. Guy Debord, The Society of the Spectacle, trans Donald Nicholson-Smith, Zone Books, New York, 1995, p 17

4. However, it should immediately be added, this is not to say that a historical consciousness cannot be maintained, but on the contrary, since its historicity is a-historical, consciousness - or, whatever consciousness it is - can only be maintained by a reconsideration of, say, Walter Benjamin's concept of Jetzeit, or Gilles Deleuzian haecceity.

5. Gilles Deleuze, Pure Immanence, trans Anne Boyman, Zone Books, New York, 2001, p 1
The broken hermaphrodite who trusted herself alone finds the room in reality teeming and begs never to wake from the nightmare. ${ }^{1}$

Sleeping Beauty in a perennial somnambulist state, is dreaming or awake, yet each of the two as the terminal point of a distance over which [s] he glides. ${ }^{2}$

\section{SEPARATION IMPERFECTED}

When Guy Debord claimed in 1967 that 'far from realising philosophy, the spectacle philosophises reality, and turns the material life of everyone into a universe of speculation', 3 he was not only alluding to the possible future bankruptcy of a speculative economy, such as we have today, but also to the two possible ways of philosophising, one of which is disrupted by the spectacle itself. As the philosophical project after Debord has developed it, philosophy, despite this disruption, could actually show an attempt to save philosophy from the rule of the specular and produce 'speculative' approaches to the speculative where even the Situationist strategy, namely the 'détournement', could be shown to have failed in bringing about 'the abolition of classes and the direct possession by the workers of every aspect of their activity' and the restoration of Marxist consciousness as such. ${ }^{4}$

Apparently, the real problem did not lie in the separation between 'image' and 'reality', which led in Baudrillard to a hypostatisation of the simulacrum, but in the availability of such terms within a general economy of the visible. If the spectacle, as Guy Debord would have it, constitutes an ur-transcendental, it does so only in a restricted economy where 'consciousness becomes a fact only if a subject is produced at the same time as the object, all three of them being outside the field and appearing as "transcendents". 5 Where the messiah cannot exit without entering, immanence is not immanent to anything, neither à la Hegel nor Marx nor in Debord's reading of the two. 
6. Debord, op cit, p 17

7. Sevim Burak, Afrika Dansl, Adam Yayıncilık, Istanbul, 1982, p 60

8. Ibid, p 15

9. In economic terms, 'an investment operation is one which, upon thorough analysis, promises safety of principal and an adequate return. Operations not meeting these requirements are speculative.' On the other hand, a positive definition of speculation in economy would be 'the assumption of considerable business risk in obtaining commensurate gain'. Whereas to gamble is 'to bet or wager on an uncertain outcome', with the assumption that one gambles for the sake of it. See http:// www.investorhome.com/ gambling.htm

10. 'The etymology of the word is as follows; from O.Fr. speculation, from L L speculationem (nom. speculatio)

"contemplation, observation", from L. speculatus, pp of speculari "observe", from specere "to look at, view". Speculator in the financial sense is first recorded 1778. Speculate is a 1599 back-formation. What is significant is the change from a passive to an active form of use. Specifically from a strict observer to one who contemplates what is observed then further to one who contemplates and acts on what they observe.' Available at: http:// en.wikipedia.org/wiki/ Speculate\#Etymology

11. Deleuze and Guattari refer to subject of enunciation vs subject of statement; see '587 BC-AD 70: On Several Regimes of Signs', in A Thousand Plateaus, trans Brian Massumi, University of Minnesota Press, Minneapolis, 1987, while Philippe LacoueLabarthe produces a distinction between subject of enunciation and subject of enunciation, in
Sarah Kane and Sevim Burak, in their own separate works, draw up a scheme in which the spectacle with all the forces of the 'speculative' comes back and deconstitutes the subject on the possibility of the extrance of the messiah into, and out of, the scene of history at any moment.

If spectacle is 'heir to all the weakness of the project of Western philosophy, which was an attempt to understand activity by means of the categories of vision', ${ }^{6}$ is there a way to negotiate the speculative out from the yoke of the specular so that the speculum of the spectacle is shattered and the 'philosophical' falls by the wayside, waiting perennially to hear the voice of the Sirens?

\section{A SINFUL MAN IS DROWNING ${ }^{7}$}

\section{SIGNIFIER/SIGNIFIED}

Speculative or dialectical thought, based on the confrontation of the contraries where the negated, despite its difference, is reduced to the structure of the same, and made to look exactly like the negator, surrenders thought to a mimetic relation between the model and copy where the same is produced via modelling the copy on a model and making it 'appear'. 'Everything that appears is good; whatever is good will appear' can only be maintained if and only if the model-copy relationship is preserved in the spectacle, ${ }^{8}$ although, according to Debord, a spectacle is a signifier which does not refer to a signified.

However, in a speculative economy, is not the spectacle a mirror for the spectator where the latter's image-value is determined by an excess of reflection?

\section{SPECTACLE/VALUE}

If in the earlier stages of capitalism, such as in financial economy, the relation between labour and value becomes visible, or appears as such only in the end product, and in the inequality between the two, in speculative economy value is made dependent on the investments of the proprietors in the market, ${ }^{9}$ and thereby left free to assume any level whatsoever depending on the circumstances. This is where the hyperbolic is introduced into the economy.

In other words, in the speculative economy, ${ }^{10}$ spectacle is produced not as something to be looked at but as something to act upon. This passage from the passive to the active use of the word is marked by an exteriority which was the dream of speculative thought in turning everything into a spectacle, and thereby paving the way for a speculative subject, that is, the subject of enunciation. ${ }^{11}$ Debord's claim that the speculative (in Hegel) creates an exteriority ${ }^{12}$ leads him to exclude the speculative in favour of the convergence of 'dialectical method and a historical taking of sides' ${ }^{13}$ This is actually where the speculative, as it is theorised by late Hegel, and Debord's dialectical method meet. 
Neither seems to be acknowledging that the speculative schema, in its attempt to conceive of the subject in isolation to produce an objective truth, will be creating an excess not only in the ways in which the speculative economy operates as the production of a valueless value but also in the de-valuation or de-constitution of the subject whose limits of reflection exceed the limits of the spectacle it aims to reflect upon. However, for Debord this valueless value applies only to the spectacle, and the subject should be saved from this valuelessness by correcting the hyperbolic and thus restoring a universal, historical consciousness.

\section{LOSS COMPENSATED}

Guy Debord conceives of spectacle as the production of a valuelessvalue where a 'commensurate gain' becomes spectacle's reinstating itself at each and every moment. That is, in Gilles Deleuze and Félix Guattari's terms, what could be considered as the 'relative de-territorialisation' of capitalism immediately re-territorialises that which it deterritorialises by virtue of its axiomatic principle. Debord's 'solution' would be the re-inscription of the historical subject taking control of its space and time in the project of achieving true historical consciousness. The re-inscription of the subject is thus a form of investment, or a speculation that wants to, against all odds, remain an investment, not having to account for any loss that has been made 'apparent' in the very system of the spectacle, only to be compensated by the next moment. If spectacle is the art of compensating for the loss of the subject by virtue of the illegitimate use of conjunctive synthesis (one could formulate it as: 'this is my life', as alienation in the form of misrecognition of oneself in one's image), with the Situationist critique one has to find one's way back into one's true life without going through the detour of the speculative. That is, without forcing the speculative to its internal outside and external inside, but instead to its outside as such, to its dialectical other. If this is not speculative in the Hegelian religious, mystical term of the

Typography: Mimesis, Philosophy, Politics, trans and ed Christopher Fynsk, Stanford University Press, California, 1989.

12. 'Since [in Hegel] the external position of thought was nevertheless maintained, this could be masked only by identifying that thought with a preexisting project of the Spirit - of that absolute heroic force which has done what it willed and willed what it has done, that force whose achievement is the present.' Debord, op cit, p 49

13. Ibid, p 50

14. Sevim Burak, Yanık Saraylar, Nisan Yayınları, Istanbul, 1993 word, it can be considered as an investment in the subject, or subject as investment, in the form of the subject of enunciation, that is, of action. But as soon as there is investment, there is no longer any safety net against speculation. What Debord had to sacrifice, in order to 'enable' the achievement of historical consciousness, was the subject of enunciation.

\section{ZERO VALUE}

Speculative surplus value is a value with no value: the zero degree of value which increases or decreases between + and - centred on a zero value. It means whatever is produced in the speculative economy produces its own value always risking a fall to zero value and even below. Spectacle in this sense is a rather tragic instrument because it owes its production grounds to a double bind which risks its own abolition carrying it to an excess... in Yanık Saraylar, ${ }^{14}$ Baron Bahar mercilessly threatens the old house owner with buying her house, in the face of which Sevim Burak produces a semiotic excess and dazzles the would-be 
proprietor with her asignifying letters, words and sentences. With the rise of the speculative and the spectacle, a hyperbole has crossed her body, and, traversing each molecule, turns it into a machine of connective synthesis. It all means that the speculative, oscillating between the proper and improper, produces an excess and strikes back the speculative with a caesura, interrupting it with a valueless value: ' $=0$ ', as Friedrich Hölderlin once put it. ${ }^{15}$

\section{CONJUNCTIVE/CONNECTIVE/DISJUNCTIVE SYNTHESES ${ }^{16}$}

If the spectacle, as recognised by Debord, works on the principle of separation which passes itself off as a universal synthesis of the image contra reality, this move raises a question about 'synthesis' that cannot be raised within the realm of the speculative unless one takes into consideration the function of the hyperbolic as a resistance to representation. All because, despite the claimed historicity of the spectacle, the spectacle, as it were, has always failed to unite what it purports to be unifying. Take, for example, Oedipus the King and Hölderlin's translation of it. Philippe Lacoue-Labarthe does not say it outright but, manoeuvre upon manoeuvre, it becomes clear in 'The Caesura of the Speculative' that Hölderlin, by translating Oedipus the King, produced one of the earliest examples of the radically speculative. ${ }^{17} \mathrm{On}$ an elementary level, if the connective synthesis informs all the partial objects in the play with an 'and' structure and wards off the coming into being of a despotic signifier, it is because the ancient play, by producing a double bind on the level of disjunctive synthesis, leads us to what is described as the 'tragic' by Nietzsche in The Birth of Tragedy. ${ }^{18}$ It is this double bind, that, hyperbologising the situation, gives way to the undecidable, of course with a warning: what the spectacle sets free as a free-floating signifier should not be appropriated by the audience. If the spectacle is supposed to create a catharsis, purification should take the form of a purification from the free-floating signifier. To suspend the decision: this is what Hölderlin detects and amplifies in his translation of Sophocles' tragedy.

\section{IMMANENCE/TRANSCENDENCE}

15. Friedrich Hölderlin, Samtliche Werke, vol 4, no $1, \mathrm{p} 274$, quoted in Typography, op cit, p 225

16. See Deleuze and Guattari, Anti-Oedipus, op cit

17. Lacoue-Labarthe, 'The Caesura of the Speculative', in Typography, op cit, pp 208-35

18. Friedrich Nietzsche, The Birth of Tragedy, trans Walter A Kaufmann, Vintage Books, New York, 1967
Sarah Kane and Sevim Burak construct their different planes of immanence by transforming what is specular in the spectacle into an aural experience. Voices snatched from what they are supposed to be representing call for an eye that can hear things. This cross-connecting of organs, one of the unavoidable results of which is tinnitus, opens the spectator or the reader to a psychasthenic universe where catharsis is reversed with a desire to 'identify' not with the figure but with the clamorous background where each voice becomes what they are only by passing through all the other voices - a situation (in the sense used by the Situationist International) where all the melody, harmony and rhythm disappear not because the mimetic disappears, but because one no longer knows how to produce the axiomatic relationship between the model and the copy in face of the rising sign of the hyperbolic. 


\section{SUBJECT}

Spectacle sets Oedipus free to find for himself what it means to be a subject of enunciation without being the subject of enunciation, a ruler of his own fate, only to teach him how wrong it is not to preserve himself as a subject modelled on a model of mimesis. Oedipus, as a figure of selfdomination, reaches us across the centuries to become the representative of 'global persons' (Nietzsche would probably call it the 'Socratic men') whose value is determined not by interiorising what is hyperbolic in speculative thought but by exteriorising it or, better, by projecting it onto the whole world where the latter becomes a Hollywood film in which the hyperbolic is exchanged with a means to a definite end.

One is poignantly reminded here of the forgotten Nietzschean game of a throw of the dice for the throw's sake. And... and... and... without yielding to a despotic signifier.

In Everest my Lord, ${ }^{19}$ the lord, the despotic spectacle, is melted away by a regime of footnotes into a pervasively maddening rhythm of a subject of enunciation just as the name of the despot is distributed along various series of voices, A, B, C, D, E, F etc until the spectacle is forced to bankruptcy in Sarah Kane's 'Crave'. ${ }^{20}$ The question is not to flesh out a subject of enunciation which assumes the voice of a yonder that connects all particular voices into a whole but, on the contrary, to wage a war against the voice, of all the voices as in a Bacon painting where institutionalisation of the Pope's throne is undercut by a deafening scream which is itself voiceless. Resonative force of the non-specular is what is reinvented by Kane and Burak.

\section{IN-BETWEEN}

The subjectification of history (in contrast to its objectification in Hegel), aiming for disalienation, misses the crucial fact of the 'encounter', while itself being a product of an encounter, albeit negated. The dialectical moment thus falls short of accounting for what happens in between; in between the subject and object, in between the 'subject' and in between the 'object'. ${ }^{21}$ Lacoue-Labarthe, in introducing literature to the question of philosophy in his own way, points to what happens in this 'in-between' of the moments of dialectic/speculative thought. Something gets lost, while it is the very movement of dialectics (reflection) that appropriates this loss as the 'appearance' of a moment of 'truth', all the time failing to account for this folding back on itself of the self (reflection) which is by definition ungraspable.

19. Sevim Burak, Everest My Lord, Yapı Kredi Yayınları, Istanbul, 2006

20. Sarah Kane, 'Crave', in Complete Plays, op cit, 2001

21. Lacoue-Labarthe, 'The Caesura of the Speculative', op cit, pp 208-35

\section{TIME/SPACE}

Only in the project of a subject conscious-to-itself, that is, only in a restricted economy can the conditions (for example, space and time) be taken fully under control; but only from a 'relatively' general economic perspective (that of the spectacle, or capitalism) can the restricted economic subject be envisioned as that which is 'possible'. When history, according to the Situationist critique, is that conception of the 
22. Debord, op cit, p 105

23. Guy Debord and Gil J Wolman, 'A User's Guide to Détournement', in Situationist International Anthology, ed and trans Ken Knab, Bureau of Public Secrets, Berkeley, California, 1995

24. Debord, op cit, p 17 irreversible time of economic production that is to be truly realised with the historical subject taking control of it, and the past (time of consumption) is that past which comes to haunt this history in order to give the illusion that nothing changes, the contradictions of this conception of history preclude the possibility of thinking the revolutionary potential in the here-and-now and subjugating it to a future that would be purified from its unconscious 'prehistory' by bringing it to light, into consciousness. ${ }^{22}$ That is, a redemptive future. History, subjected to a restricted 'historical' understanding as succession, can only dream of its future as it does of its past. That is, by negating the present, the possibility of haecceity.

\section{DETOURNEMENT}

The recent economic crisis can be considered as the catharsis of speculative thought and economy but it will never bring about the bankruptcy of the spectacle nor will it celebrate the triumph of détournement. Although the latter was a critique of speculative value production, it only ended up in a new moment of the Aufhebung in art and art criticism due to its appropriation of the speculative per se, thereby eliminating the possibility of an appropriation of a schizophrenic value into the deconstitution of 'global persons'. Détournement still preserves the mimetic because it cannot give up the dialectical claim to identity: even though two disparate and distant objects are juxtaposed to give the lie to representation, the resulting work is not less or more radical than Marcel Duchamp's addition of a moustache to the Mona Lisa, as long as the original contexts of the disparate objects remain unavoidably detectable ${ }^{23}$ and lead to a type of synthesis which Deleuze and Guattari called an illegitimate use of conjunctive synthesis. The latter's legitimate use is described by the philosophers as the movement of a signifier beyond and over an 'and... and... and' and 'either/or' structure - in short, a schizophrenic naming of things in which each word, traversing each and every other possible word, syllable and sound, restructures the world anew each time immanently.

In détournement juxtaposition forces the speculative to an excess, the production of which is short-circuited by the mimetic, and therefore what is speculated still remains as spectacle. If the conjunctive synthesis produces a valueless, nomadic value, the failure of détournement can be found in its appropriation of the speculative as such without appropriating the schizophrenic or nomadic value into the constitution of the subject of enunciation. In this sense, détournement comes only after the event, only after the primary identification, that is, after, just as in spectacle, it fulfils the function of an ur-mirror, ur-spect so as to reflect an ur-model which determines all the copies.

\section{CRISIS}

'For one to whom the real world becomes real images, mere images are transformed into real beings - tangible figments which are the efficient motor of trancelike behavior.'24 
25. 'c. 1425 , from Gk. krisis "turning point in a disease" (used as such by Hippocrates and Galen), literally "judgment", from krinein "to separate, decide, judge", from PIE base "krei- "to sieve, discriminate, distinguish" (cf .Gk. krinesthai "to explain"; O.E. hriddel "sieve"; L cribrum "sieve", crimen "judgment, crime", cernere (pp. cretus) "to sift, separate"; O. Ir. criathar, O. Welsh cruitr "sieve"; M Ir crich "border, boundary"). Transferred non-medical sense is 1627 . A Ger. term for "mid-life crisis" is Torschlusspanik, lit. "shut-door-panic", fear of being on the wrong side of a closing gate.' Available online at: http:// www.etymonline.com/ index.php?term=crisis

26. Georg Büchner, Complete Works and Letters, eds Walter Hinderer and Henry J Schmidt, trans Henry J Schmidt, Continuum, New York, 1991

27. See Onno van der Hart and Barbara Friedman, 'A Reader's Guide to Pierre Janet on Dissociation: A Neglected Intellectual Heritage', Dissociation, 2:1, March 1989; and Pierre Janet, The Major Symptoms of Hysteria, Macmillan, London and New York, 1920

28. Kane, ‘4.48 Psychosis’, op cit, p 209

29. Word coined with reference to Jacques Derrida's 'subjectile' in 'Maddening the Subjectile', Yale French Studies, 84, 1994, pp 154-71
Something - in between Nothing and Being - happened in the nineteenth century and since then the abyss yawning between the restrictive and the general, rejecting the Hegelian diagnosis (dialectics) of the Kantian caesura of 'the thing-in-itself' and 'the thing-for-itself', is continuously giving rise to a 'crisis' in general. Crisis etymologically comes from the Ancient Greek ' $\kappa$ 'í⿴\zh11⿰' (krisis) meaning 'turning point in a disease for better or worse', with several connotations such as, 'to separate, decide and judge'. ${ }^{25}$

Georg Büchner's monumental story, 'Lenz', ${ }^{26}$ bears witness to a 'crisis' as to whether the landscape or space is available as a distinct field of inspection as separate from the traveller. The way Büchner produces an answer to the dichotomy of man and nature - almost as against, say, Freudian psychoanalysis in the later part of the nineteenth century where the division within the 'self' will be attributed to an illness, named 'schizophrenia', by way of unproblematically determining the place where a possible division between the unconscious and the conscious might have taken place - offers a strange operation of separation which is a separation from a 'self' with the intention of melting into landscape, thereby confusing the boundaries between topological and atopological.

In terms of early nineteenth-century psychiatry, especially the work of Pierre Janet, 'dementia', or better, 'psychasthenia', ${ }^{27}$ is an ultimate form of dissociation, the main symptom of which is somnambulism, where the patient is in a state of hypnosis with no one to mime, no model to imitate, or better, where any form of role playing or imitation which establishes 'reality' as such is out of question. In other words, what is at stake in psychasthenia is a certain relationship to the 'spatial' where the boundaries between topological and atopological are confused, and one cannot locate oneself in time and space:

And I am deadlocked by that smooth psychiatric voice of reason which tells me there is an objective reality in which my body and mind are one. But I am not here and never have been. ${ }^{28}$

Now if the crisis, or 'the turning point in disease for better or worse', of the 'subject' can be interpreted as a perennial crisis of the schism between the subject of enunciation and the subject of enunciation who fails to partake in the speculative in its constitution, a spectacularly speculative spectacle can give rise to a subject-in-crisis, the spectile, ${ }^{29}$ the 'turning points' of which will be topologically indeterminable, or better, undecidable as in a hypnotic séance where the question of transference blurring the boundaries between the patient and the analyst turns the whole scene into a spectacle with no spectator.

\section{CONSCIOUSNESS}

If Marxist class consciousness, as it was appropriated from the Hegelian concept of 'universal consciousness', has failed to put the spectators into a hypnotic state, its reasons should be sought in the dangers of hypnosis 
which are well accounted for by Freud. ${ }^{30}$ The ensuing rise of Oedipal figures and micro-fascism on each and every level today is due to an insistence on the necessity of self-identical subjects shared by Hegel, Marx and the Situationists. Otherwise, in a realm where hypnosis rules, despotism of the spectacle is bound to disappear, at the same time warding off Oedipus so that he cannot step into our dreams.

How can we hypnotise the Father, or Hegel? Or better, how can we maintain a drowsy-Hegel not quite awake yet? What if the father is hypnotised so that he can be made to confess his trauma? Isn't it timely to radicalise détournement as a way of producing the un-Gestalt of a whatever-image? How can we hypnotise the Father, Hegel or Freud so that psychoanalysis itself is forced to lead the life of a somnambulist?

\section{ASYMPTOTE}

When the logic of the hyperbolic introduces the irreducibility of difference, through the irrecuperable loss of the subject, the irreducibility of difference per se is what is at stake. In its positive aspect, that is, if loss is not only loss 'of the subject' but that loss which cannot be reintroduced into a given economy (which may amount to the same thing), it is also that which produces its 'other' that is no longer its dialectical opposite but the asymptotic relation of not one but two which were never unified in the first place, a pre-subjective becoming. Asymptote as the affirmation of divergence - to say no 'without being a no-saying spirit'. ${ }^{31}$

\section{BECOMING-WOMAN/BECOMING-SPECULATIVE}

30. See especially Mikkel Borch-Jacobsen's The Emotional Tie: Psychoanalysis, Mimesis and Affect, Stanford University Press, California, 1992

31. Friedrich Nietzsche, Ecce Homo, trans R J Hollingdale, Penguin Classics, London, 1992

32. Deleuze and Guattari, '1730: Becoming-Intense, Becoming-Animal, BecomingImperceptible...', in $A$ Thousand Plateaus, op cit

33. Kane, '4.48 Psychosis', op cit,
Becoming-woman therefore is not the first phase of becoming, 32 but becoming itself, which already entails a becoming speculative that no longer oscillates between two poles but is itself the proliferation of poles, the emphasis being on proliferation rather than on poles. Becomingspeculative as the impossibility of becoming-man. Spectacle as the mirror which does not reflect man back to him but reflects infinitely, as proliferation of images, the shattering of the speculum. Or rather, the speculum was shattered all along. Becoming-speculative as not the becomingimage but becoming 'of' the image. What would the becoming-woman of the image be? What a waste!

That which is made to appear as the burden of any given economy refuses 'tolerability, bearability' as the refusal of burden. '4.48 Psychosis' is thus not the crisis of a certain woman but the crisis of an economy (of love) itself, 33 of man as restricted economy: becoming-woman or Vincent Van Gogh's At Eternity's Gate.

The undecidable is what lies between one's eyelids. 